J. Mark K. H. Wierda MD, Gerhard F. Karliczek MD PhD, Ron H. G. Vandenbrom MD PharmD, Igal Pinto, Ursula W. Kersten-Kleef BS,

Dirk K. F. Meijer, PharmD PhD, * Sandor Agoston MD PhD

\section{Pharmacokinetics and cardiovascular dynamics of pipecuronium bromide during coronary artery surgery}

Nous avons comparé les effets du pipécuronium et du pancuronium à raison de $200 \mu \mathrm{g} \cdot \mathrm{kg}^{-1}$ sur l'hémodynamie de 20 sujets lors de leurs revascularisations coronariennes. Nous mesurions ces effets pendant une période de dix minutes sous anesthésie à l'étomidate et au piritramide, ce dernier étant ensuite remplacé par du sufentanil. Nous avons observé avec le pipécuronium et le pancuronium respectivement, des changements moyens de -19 et de -2 pour cent quant au débit cardiaque et de -1 et +26 pour cent quant au pouls. Par la mesure de ses concentrations plasmatiques et urinaires, nous avons pu établir que le pipécuronium encours une redistribution initiale rapide $\left(t_{i}=\right.$ $7.6 \mathrm{~min})$ suivie d'une élimination plus lente $\left(t_{1}=161 \mathrm{~min}\right)$ avec un volume de distribution central estimé à $102 \pm 24$ $\mathrm{ml} \cdot \mathrm{kg}^{-1}$ et une clairance plasmatique de $1,8 \pm 0,4 \mathrm{ml}$. $\mathrm{kg}^{-1} \cdot \mathrm{min}^{-1}$. En moins de 24 heures, on a retrouvé dans les urines, près de 56 pour cent du pipécuronium injecté dont le quart sous forme de son métabolite, le 3-désacéryl pipécuronium. Avec le type d'anesthésie employé, l'injection à bonne dose de pipécuronium n'a donc pas entrainé d'effet hémodynamique néfaste. De plus, la cinétique d' un bolus de ce médicament s'est révélée semblable à celle observée en normothermie.

Pipecuronium bromide ( 2 beta, 16 beta-bis( $4^{\prime}$-dimethyll'-piperazino)-3 alpha, 17 beta-diacetoxy- 5 alpha-androstane dibromide; Arduan ${ }^{(8)}$ ) is a steroidal neuromuscular blocking agent, resembling pancuronium bromide not only in its chemical structure (Figure 1), but also in the potency and time-course of its neuromuscular blocking effects. ${ }^{1,2}$ The pharmacokinetic behaviour of this drug has been studied in animals ${ }^{3-5}$ and in patients with normal and impaired renal function ${ }^{6.7}$ although the study in humans by Tassonyi, ${ }^{6}$ did not allow a proper pharmacokinetic analysis because of the limited duration of blood sampling. Earlier studies ${ }^{1,3,9-13}$ both in animals and man have shown that the cardiovascular effects of this agent are minimal, lacking ganglion-blocking and/or histaminereleasing properties. ${ }^{3}$ Pipecuronium does not affect myo- 

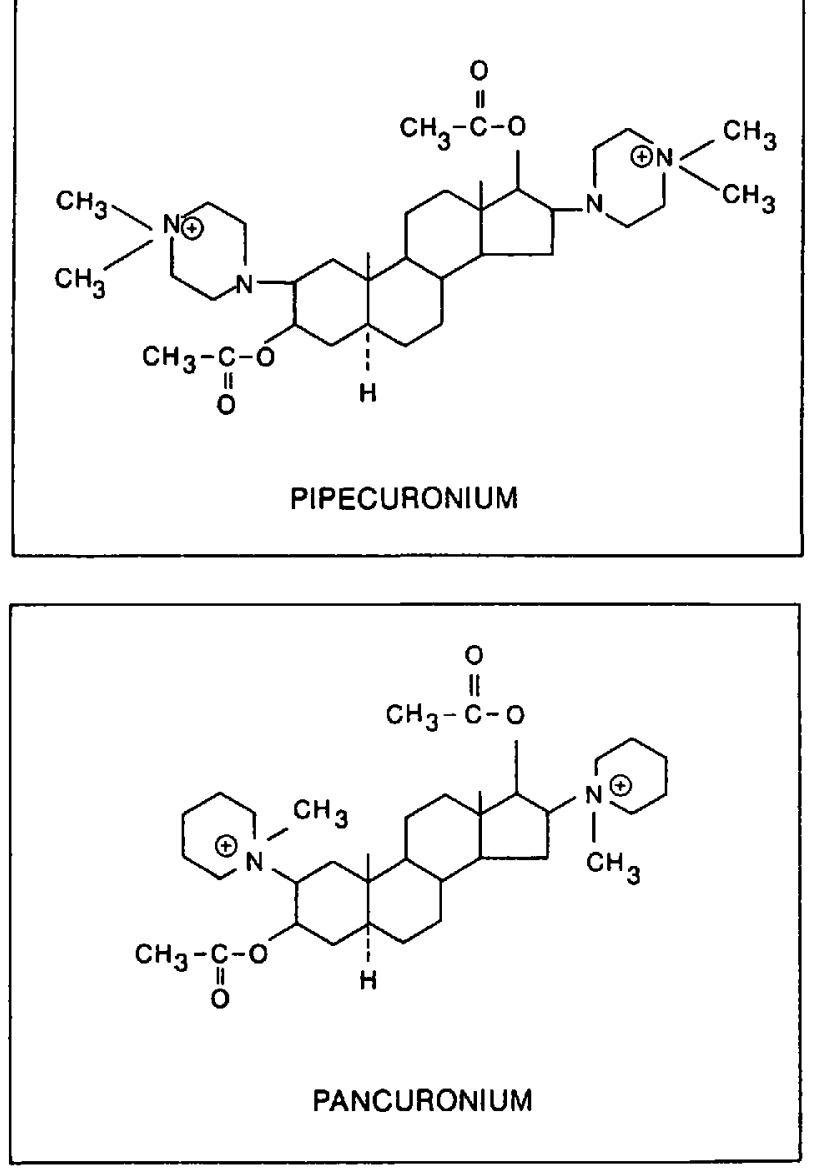

FIGURE 1 Structural formulas pipecuronium and pancuronium.

cardial blood supply or myocardial oxygen consumption in animals. ${ }^{10}$ Barankay ${ }^{14}$ suggested that, because of the absence of cardiovascular side-effects, it was a suitable agent for patients with severe cardiovascular disease. The present study was undertaken to investigate the haemodynamic effects and the pharmacokinetic disposition of a single bolus dose of pipecuronium, which was sufficient both for the conditions of the pharmacokinetic study and the duration of the surgical intervention.

\section{Methods}

\section{Patients}

The study was approved by the Ethical Committee of the University Hospital of Groningen. Twenty patients, scheduled for elective coronary artery surgery, ASA physical status class III, gave informed consent to participate in this study. Their age was between 21 and 65 $\mathrm{yr}$, with a mean of $54 \mathrm{yr}$. Patients with a history of cardiac failure, valvular, or myocardial disease were excluded. In ten patients a dose of $200 \mu \mathrm{g} \cdot \mathrm{kg}^{-1}$ (approximately four times the effective dose producing a neuromuscular blockade of 95 per cent) was administered, sufficient to cover the duration of surgery. The pharmacokinetic profile and cardiovascular responses to pipecuronium were studied. In order to compare the cardiovascular responses between both neuromuscular blocking agents, a matched control group $(n=10)$ received an equipotent dose of pancuronium $\left(200 \mu \mathrm{g} \cdot \mathrm{kg}^{-1}\right)$.

\section{Anaesthesia}

Premedication consisted of butobarbitone, $100 \mathrm{mg}$ orally on the evening before the operation and diazepam, 10-15 $\mathrm{mg}$ orally approximately $1.5 \mathrm{hr}$ before the induction of anaesthesia. Cardiac maintenance medication was continued. After arrival in the operating room, peripheral venous, systemic arterial, central venous and pulmonary arterial (Swan-Ganz) lines were established under local anaesthesia. Following attachment of the monitoring devices a five minute-period was allowed for stablisation of the cardiovascular system and baseline measurements were obtained. Anaesthesia was induced with a bolus of piritramide $0.3 \mathrm{mg} \cdot \mathrm{kg}^{-1}$, followed by an infusion of etomidate at a rate of $50 \mu \mathrm{g} \cdot \mathrm{kg}^{-1} \cdot \mathrm{min}^{-1}$. Once unconscious, the patients' lungs were ventilated with 100 per cent oxygen. End-tidal $\mathrm{PCO}_{2}$ was kept between 3.5 and $4.5 \mathrm{kPa}$. When a stable level of anaesthesia had been achieved, $200 \mu \mathrm{g} \cdot \mathrm{kg}^{-1}$ pipecuronium or pancuronium dissolved in $10 \mathrm{ml}$ saline was injected IV over a ten seconds interval. Prior to administration ( $t=0$ mins) and for nine minutes thereafter haemodynamic measurements (Table II) were carried out continuously, with the exception of cardiac output measured by thermodilution and wedge pressure, which were estimated at threeminutes intervals.

This period was followed by tracheal intubation and the commencement of surgery. After the cardiovascular part of the study was completed anaesthesia was maintained with a continuous infusion of etomidate and sufentanil, according to the needs of the patient. The time elapsing between induction of anaesthesia and commencement of extracorporeal circulation averaged $105 \mathrm{~min}$. The lowest temperature during surgery ranged from $28.8-25.6^{\circ} \mathrm{C}$ and the duration of bypass from 79 to $152 \mathrm{~min}$ (mean 109 min) respectively. Patients were rewarmed by extra corporeal circulation, usually until nasopharyngeal temperature had reached $37.5^{\circ} \mathrm{C}\left(\Delta \mathrm{T} 3-4^{\circ} \mathrm{C}\right)$. Thereafter central temperature again slowly decreased reaching a value at the end of the surgical procedure of approximately $35^{\circ} \mathrm{C}\left(\Delta \mathrm{T} 5-6^{\circ} \mathrm{C}\right)$.

All haemodynamic measurements were graphically displayed and stored in a Carola Database system developed in the department. ${ }^{15}$ The measurements were used to calculate stroke volume index (SVI), left 
ventricular stroke work index (LVSWI), systemic vascular resistance (SVR), rate pressure product (RPP), triple index (TI), and left ventricular power (LV power). Statistical analysis was performed with the (un-)paired Student's $t$ test and if necessary the Wilcoxon rank sum test. A value of $P<0.05$ was considered to be significant.

\section{Procedure of the kinetic study}

Blood samples $(8 \mathrm{ml})$ were collected via a central venous line. The first sample was taken before administration of pipecuronium, the others were collected $2,4,6,8,10,15$, $20,30,45,60,90,120,180,240,360$ and 480 min after the end of injection. Additional blood samples were taken five minutes after the start of extracorporeal circulation and immediately at the end of cardiopulmonary bypass. In order to prevent spontaneous degradation of pipecuronium, the samples were immediately acidified with $2 \mathrm{ml} 1 \mathrm{M}$ sodium di-hydrogen phosphate $\left(\mathrm{NaH}_{2} \mathrm{PO}_{4}\right)$ solution to prevent spontaneous deacetylation. The plasma was separated by centrifuge and frozen, $-18^{\circ} \mathrm{C}$, to await analysis. Urine was collected over 24 hours and well mixed samples were taken from a previously inserted urethral catheter prior to and at $2,4,6,8,12,18$ and $24 \mathrm{hr}$ after the administration of pipecuronium. Ten $\mathrm{ml}$ aliquots of the samples were frozen until analysis could be performed. Analysis was carried out by a fluorimetric method combined with thin-layer chromatography (TLC), based on the method described for pancuronium bromide. ${ }^{16}$ The detection limit of pipecuronium in plasma and urine was $25 \mathrm{ng} \cdot \mathrm{ml}^{-1}$. The standard deviation of pipecuronium fluorescence of plasma levels in the range from $25 \mathrm{ng} \cdot \mathrm{ml}^{-1}$ to $1500 \mathrm{ng} \cdot \mathrm{ml}^{-1}$ varied from 0.3 $\mathrm{ng} \cdot \mathrm{ml}^{-1}$ (11.9 per cent of mean) at the lower level and 35 $\mathrm{ng} \cdot \mathrm{ml}^{-1}$ (3.2 per cent of mean) at the higher level. The assay accuracy over the same range varied from 11.3 to 2.1 per cent.

Pharmacokinetic analysis was performed on the individual data by means of a computer program, based on iterative linear least-square regression analysis. ${ }^{17}$ The volume of the central compartment $\left(V_{1}\right)$, the apparent distribution volume $\left(\mathrm{V}_{\mathrm{d} \beta}\right)$, the total plasma clearance $(\mathrm{CL})$ and the area under the curve (AUC) were calculated, using the following equations:

$$
\begin{aligned}
& \text { [1] } V_{1}=\frac{\text { Dose }}{C_{1}+C_{2}} \\
& \text { [2] } V_{d \beta}=\frac{\text { Dose }}{\text { AUC } \cdot \lambda_{2}} \\
& \text { [3] } C L=\frac{\text { Dose }}{A U C} \\
& \text { [4] AUC }=\frac{C_{1}}{\lambda_{1}}+\frac{C_{2}}{\lambda_{2}}
\end{aligned}
$$

The values for renal clearance were calculated using the equation:

$$
\text { [5] } \quad \mathrm{CL}_{R}=\frac{\mathrm{A}_{\mathrm{U}\left(\mathrm{t}_{\mathrm{i}}-\mathrm{t}_{\mathrm{j}}\right)}}{\mathrm{AUC}_{\left(\mathrm{t}_{\mathrm{i}}-\mathrm{j}_{\mathrm{j}}\right)}}
$$

$t_{i}$ and $t_{j}$ indicate the time interval of urine collection. $A_{u\left(t_{i}-t_{j}\right)}$ is the renally excreted amount during the sampling period, and $\mathrm{AUC}_{\left(\mathrm{t}_{i}-\mathfrak{t}_{\mathrm{j}}\right)}$ is the area under the plasma concentration decay curve between the two times and was calculated using the equation

[6] $\mathrm{AUC}_{\left(\mathrm{t}_{i}-\mathrm{t}_{\mathrm{j}}\right)}=\frac{\mathrm{C}_{1}}{\lambda_{1}}\left(\mathrm{e}^{-\lambda_{1} \mathrm{t}_{i}}-\mathrm{e}^{-\lambda_{1} \mathrm{t}_{j}}\right)+\frac{\mathrm{C}_{2}}{\lambda_{2}}\left(\mathrm{e}^{-\lambda_{2} \mathrm{t}_{4}}-\mathrm{e}^{-\lambda_{2} \mathrm{t}_{j}}\right)$

$C_{1}$ and $C_{2}$ are the concentrations at $t=0$ obtained by extrapolation of the initial rapid and second slow component of the semilogarithmic plotted curves. $\lambda_{1}$ and $\lambda_{2}$ are the hybrid rate constants respectively.

\section{Results}

\section{Haemodynamic study}

The preoperative data of all 20 patients are summarized in Table I. There were no significant differences between the two groups in age, weight, basal heart rate (HR), systolic (SSAP) and diastolic (DSAP) systemic arterial pressures, left ventricular end-diastolic pressure (LVEDP) and New York Heart Association Class (NYHA). It should be noted that there were no females in the pipecuronium group, whereas in the pancuronium group four of the ten patients were females. Patients were not stratified regarding their preoperative cardiac medication, hence coexisting cardiac medication was variable between the two groups. Beta sympathetic blocking drugs were taken by five patients in the pipecuronium group and by eight patients in the pancuronium group. Comparable numbers with regard to calcium antagonists were seven and ten for patients in the pipecuronium and pancuronium groups respectively. The data from the haemodynamic measure-

TABLE I Preoperative characteristics and haemodynamic variables for both groups (mean (SEM))

\begin{tabular}{llcc}
\hline & & $\begin{array}{l}\text { Pipecuronium } \\
(n=10)\end{array}$ & $\begin{array}{l}\text { Pancuronium } \\
(n=10)\end{array}$ \\
\hline Age & $\mathrm{yr}$ & $53.5(2.1)$ & $58.7(2.7)$ \\
Weight & $\mathrm{kg}$ & $82.5(2.8)$ & $76.8(2.8)$ \\
HR & $\mathrm{bpm}$ & $68.0(1.8)$ & $69.0(2.6)$ \\
SSAP & $\mathrm{mmHg}$ & $146(6.3)$ & $143(6.0)$ \\
DSAP & $\mathrm{mmHg}$ & $87(3.2)$ & $81(1.9)$ \\
LVEDP & $\mathrm{mmHg}$ & $15.6(2.6)$ & $14.5(1.7)$ \\
NYHA class & - & $2.7(0.2)$ & $2.8(0.1)$ \\
\hline
\end{tabular}

HR = heart rate, SSAP = systolic systemic arterial pressurc, DSAP = diastolic systemic arterial pressure, LVEDP = left ventricular enddiastolic pressure. 
TABLE II Haemodynamic measurements prior to $(0 \mathrm{mins})$ and following an intravenous bolus dose of $200 \mu \mathrm{g} \cdot \mathrm{kg}^{-1}$ pancuronium (pip) or $200 \mu \mathrm{g} \cdot \mathrm{kg}^{-1}$ pancuronium (pan) (mean $\pm \mathrm{SEM}$ )

\begin{tabular}{|c|c|c|c|c|c|}
\hline \multirow[b]{2}{*}{ Variable } & \multicolumn{5}{|l|}{ Time (mins) } \\
\hline & 0 & 3 & 6 & 9 & \\
\hline HR bpm & $\begin{array}{l}58.5 \pm 2.2 \\
58.5 \pm 4.3\end{array}$ & $\begin{array}{l}57.3 \pm 3.6 \\
64.2 \pm 4.9\end{array}$ & $\begin{array}{l}56.7 \pm 2.2 \\
69.9 \pm 5.9\end{array}$ & $\begin{array}{l}58.0 \pm 2.2 \\
73.5 \pm 8.2\end{array}$ & $\begin{array}{l}\text { pip } \\
\text { pan }\end{array}$ \\
\hline SSAP mmHg & $\begin{array}{l}124 \pm 5.7 \\
128 \pm 5.4\end{array}$ & $\begin{array}{l}114 \pm 4.7 \\
117 \pm 7.6\end{array}$ & $\begin{array}{l}107 \pm 3.8 \\
115 \pm 6.6\end{array}$ & $\begin{array}{l}107 \pm 3.2 \\
115 \pm 6.6\end{array}$ & $\begin{array}{l}\text { pip } \\
\text { pan }\end{array}$ \\
\hline DSAP $\mathrm{mmHg}$ & $\begin{array}{l}69.5 \pm 3.3 \\
65.0 \pm 2.6\end{array}$ & $\begin{array}{l}62.3 \pm 3.5 \\
62.0 \pm 5.4\end{array}$ & $\begin{array}{l}61.3 \pm 2.0 \\
60.0 \pm 5.7\end{array}$ & $\begin{array}{l}61.4 \pm 2.3 \\
64.0 \pm 5.1\end{array}$ & $\begin{array}{l}\text { pip } \\
\text { pan }\end{array}$ \\
\hline CVP $\mathrm{mmHg}$ & $\begin{array}{l}9.1 \pm 1.3 \\
9.2 \pm 0.9\end{array}$ & $\begin{array}{l}7.7 \pm 1.0 \\
7.8 \pm 0.7\end{array}$ & $\begin{array}{l}7.2 \pm 1.2 \\
7.7 \pm 0.7\end{array}$ & $\begin{array}{l}6.6 \pm 1.1 \\
8.2 \pm 0.7\end{array}$ & $\begin{array}{l}\text { pip } \\
\text { pan }\end{array}$ \\
\hline SPAP mmHg & $\begin{array}{l}28.5 \pm 1.9 \\
30.2 \pm 2.7\end{array}$ & $\begin{array}{l}25.6 \pm 1.6 \\
28.1 \pm 1.6\end{array}$ & $\begin{array}{l}24.2 \pm 1.4 \\
26.8 \pm 1.8\end{array}$ & $\begin{array}{l}23.5 \pm 1.2 \\
27.8 \pm 2.7\end{array}$ & $\begin{array}{l}\text { pip } \\
\text { pan }\end{array}$ \\
\hline DPAP $\mathrm{mmHg}$ & $\begin{array}{l}12.4 \pm 1.6 \\
12.8 \pm 1.1\end{array}$ & $\begin{array}{l}11.2 \pm 1.6 \\
10.7 \pm 1.3\end{array}$ & $\begin{array}{l}10.0 \pm 1.2 \\
10.1 \pm 1.4\end{array}$ & $\begin{array}{l}10.5 \pm 1.4 \\
10.9 \pm 1.9\end{array}$ & $\begin{array}{l}\text { pip } \\
\text { pan }\end{array}$ \\
\hline PCWP mmHg & $\begin{array}{l}12.5 \pm 1.2 \\
12.2 \pm 0.6\end{array}$ & $\begin{array}{l}10.5 \pm 1.3 \\
11.2 \pm 0.9\end{array}$ & $\begin{array}{l}10.1 \pm 1.1 \\
10.0 \pm 1.2\end{array}$ & $\begin{array}{r}9.4 \pm 1.1 \\
11.1 \pm 1.3\end{array}$ & $\begin{array}{l}\text { pip } \\
\text { pan }\end{array}$ \\
\hline $\mathrm{CO} I \mathrm{~min}^{-1}$ & $\begin{array}{l}4.7 \pm 0.4 \\
5.5 \pm 0.7\end{array}$ & $\begin{array}{l}4.1 \pm 0.3 \\
5.1 \pm 0.7\end{array}$ & $\begin{array}{l}4.1 \pm 0.2 \\
5.4 \pm 1.6\end{array}$ & $\begin{array}{l}3.8 \pm 0.3 \\
5.4 \pm 0.7\end{array}$ & $\begin{array}{l}\text { pip } \\
\text { pan }\end{array}$ \\
\hline
\end{tabular}

HR $=$ heart rate, SSAP = systolic systemic arterial pressure, DSAP = diastolic systemic arterial pressure, $\mathrm{CVP}=$ central venous pressure, $\mathrm{SPAP}=$ systolic pulmonary arerial pressure, $\mathrm{DPAP}=$ diastolic pulmonary arterial pressure, $\mathrm{PCWP}=$ pulmonary capillary wedge pressure, $\mathrm{CO}=$ cardiac output.

TABLE III Hacmodynamic values [mean (SEM)] after induction of anaesthesia, just before and 9 min after the administration of pipecuronium $\left(200 \mu \mathrm{g} \cdot \mathrm{kg}^{-1}\right)$ or pancuronium $\left(200 \mu \mathrm{g} \cdot \mathrm{kg}^{-1}\right)$ in patients scheduled for CA surgery

\begin{tabular}{|c|c|c|c|c|}
\hline \multirow{2}{*}{$\begin{array}{l}\text { Haemodynamic } \\
\text { variables }\end{array}$} & \multicolumn{2}{|c|}{ Pipecuronium } & \multicolumn{2}{|c|}{ Pancuronium } \\
\hline & $0 \min$ & $9 \min$ & $0 \min$ & $9 \min$ \\
\hline HR $\min ^{-1}$ & $58.5(2.2)$ & $58(2.2)$ & $58.5(4.3)$ & $73.5(8.2)^{\dagger}{ }^{*}$ \\
\hline SSAP mmHg & $124(5.7)$ & $107(3.2) \dagger$ & $128(5.4)$ & $115(6.6) \dagger$ \\
\hline DSAP mmHg & $69(3.3)$ & $61(2.3) \dagger$ & $65(2.6)$ & $64(5.1)$ \\
\hline CVP mmHg & $9.1(1.3)$ & $6.6(1.1) \dagger$ & $9.2(0.9)$ & $8.2(0.7)$ \\
\hline SPAP $\mathrm{mmHg}$ & $29(1.9)$ & $24(1.2) \dagger$ & $30(2.7)$ & $28(2.7)$ \\
\hline DPAP mmHg & $12(1.6)$ & $11(1.4)$ & $13(1.1)$ & $11(1.9)$ \\
\hline PCWP mmHg & $13(1.2)$ & $9(1.1)^{t}$ & $12(0.6)$ & $11(1.3)$ \\
\hline CPP mmHg & $57(2.3)$ & $52(1.7)$ & $53(1.6)$ & $53(3.2)$ \\
\hline $\mathrm{CO} I \mathrm{~min}^{-1}$ & $4.7(0.4)$ & $3.8(0.3) \dagger$ & $5.5(0.7)$ & $5.4(0.7)^{*}$ \\
\hline $\mathrm{SVI} \mathrm{ml} \cdot \mathrm{m}^{-2}$ & $42(3.2)$ & $35(3.1)$ & $50(5.1)$ & $40(3.6)$ \\
\hline $\mathrm{SVR}$ dyn $\cdot \mathrm{s} \cdot \mathrm{cm}^{-5}$ & $1444(152)$ & $1542(128)$ & $1231(114)$ & $1192(143)^{*}$ \\
\hline $\mathrm{RPP} \operatorname{mmHg} \min ^{-1} \cdot 10^{-3}$ & $7.3(0.5)$ & $6.2(0.4) \dagger$ & $7.6(0.8)$ & $8.8(1.6)^{*}$ \\
\hline $\mathrm{TI} \mathrm{mmHg}^{2} \min ^{-1} \cdot 10^{-3}$ & $94(12.3)$ & $60(8.5)$ & $92(10.2)$ & $114(32.5)^{*}$ \\
\hline LVSWI $\mathrm{nm}^{-2}$ & $43(4.6)$ & $32(3.0) \dagger$ & $50(5.9)$ & $37(3.1) \dagger$ \\
\hline LV power & $0.8(0.01)$ & $0.6(0.01) \dagger$ & $0.95(0.02)$ & $0.9(0.02)^{*}$ \\
\hline
\end{tabular}

HR = hear rate, SSAP = systolic systemic arterial pressurc, DSAP = diastolic systemic arterial pressure, $\mathrm{CVP}=$ central venous pressure, $\mathrm{SPAP}=$ systolic pulmonary arterial pressure, $\mathrm{DPAP}=$ diastolic pulmonary arterial pressure, $\mathrm{PCWP}=$ pulmonary capillary wedge pressure, $\mathrm{CPP}=$ coronary perfusion pressure, $\mathrm{CO}=$ cardiac output, $\mathrm{SVI}=$ stroke volume index, $\mathrm{SVR}=$ systemic vascular resistance, $\mathrm{RPP}=$ rate pressure product. $\mathrm{Tl}=$ triple index, $\mathrm{LVSWI}=$ left ventricular stroke work index, $\mathrm{LV}$ power $=$ left ventricular power.

Statistical significance:

*unpaired $t$ test $/$ ilcoxon test. $P<0.05$. Inter-group at 0 and 9 minutes.

tpaired t test. $P<0.05$. Intra-group between 0 and 9 minutes. 


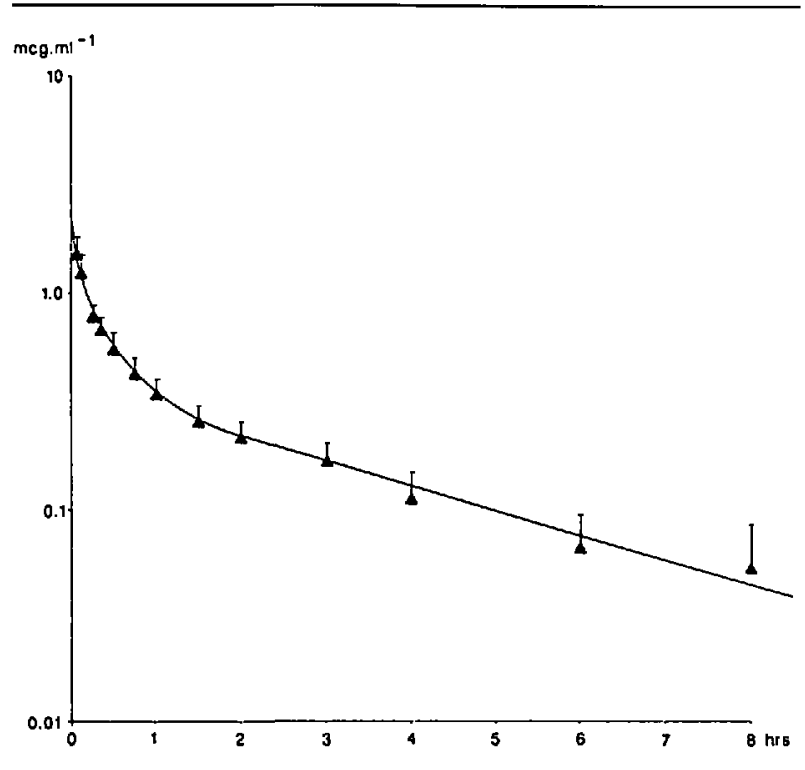

FIGURE 2 Mean plasma concentration decay curve of pipecuronium following a dose of $200 \mu \mathrm{g} \cdot \mathrm{kg}^{-1}$ intravenously (mean $\pm \mathrm{SD}$ )

ments are shown in Table II. Table III compares the mean values in and among the two groups, calculated from the measurements prior to the administration of the neuromuscular blocking agents $(0 \mathrm{mins})$ and those obtained at nine minutes after injection. In most patients in the pancuronium group a moderate but consistent increase in heart rate was measured. However, two patients developed a more pronounced tachycardia. In addition to the increase in heart rate there was a significant decrease in the systemic systolic arterial pressure and in the left ventricular stroke work index. However, in the pipecuronium group a greater number of significant changes were observed. The SSAP, DSAP, CVP, SPAP, and the PCWP decreased significantly during the measuring period. The values for cardiac output, RPP, LVSWI, and LV power decreased simultaneously. Heart rate did not change with time and was not influenced by the presence or absence of beta-adrenergic blocking agents. Comparison between the two groups shows no significant differences in the measured and calculated values at zero minutes. However, at nine minutes, patients in the pancuronium group had a significantly higher heart rate and cardiac output. Derived values such as RPP, TI and LV power were also significantly higher in the pancuronium treated group.

\section{Pharmacokinetic study}

The mean plasma concentration decay curve of pipecuronium, following an intravenous dose of $200 \mu \mathrm{g} \cdot \mathrm{kg}^{-1}$, is shown in Figure 2. The derived variables are listed in Table IV. The cumulative urinary excretion of pipecuron-

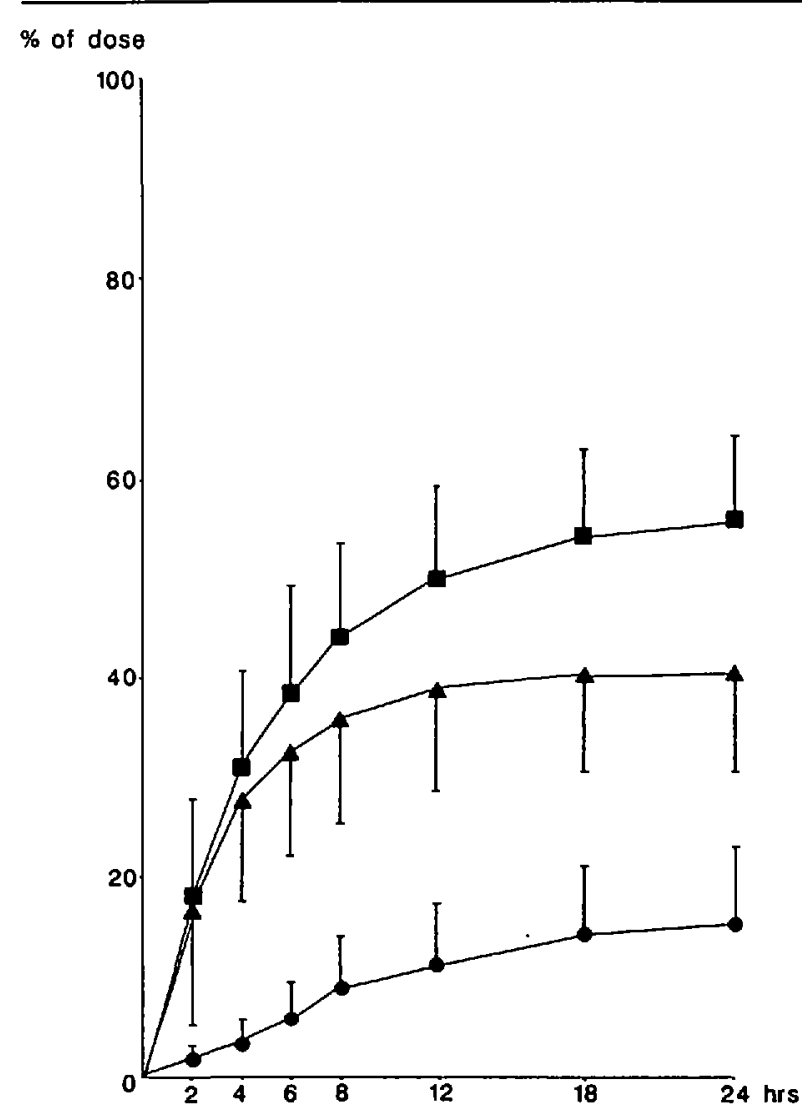

FIGURE 3 Mean cumulative urinary excretion of pipecuronium $(\Delta), 3$-desacetyl pipecuronium $(\boldsymbol{O})$, and the total $(\square)$ urinary excretion. The vertical bars indicate the standard deviation $(n=10)$

ium and the only metabolite (3-desacetyl pipecuronium) found so far are shown in Figure 3. The potential 17-OH and the 3,17-diOH metabolites could neither be demonstrated in plasma nor in urine. The $3-\mathrm{OH}$ metabolite also did not reach detectable plasma levels using the present

TABLE IV Pharmacokinetic variables of pipecuronium bromide following an intravenous bolus dose of $200 \mu \mathrm{g} \cdot \mathrm{kg}^{-1}$ in patients undergoing coronary artery surgery (mean $\pm \mathrm{SD}$ )

\begin{tabular}{llc}
\hline Variables & \multicolumn{2}{l}{ Units } \\
\hline $\mathrm{C}_{1}$ & $\mu \mathrm{g} \cdot \mathrm{ml}^{-1}$ & $1.58 \pm 0.47$ \\
$C_{2}$ & $\mu \mathrm{g} \cdot \mathrm{ml}^{-1}$ & $0.406 \pm 0.106$ \\
$\mathbf{I}_{\text {alpha }}$ & $\mathrm{min}$ & 7.6 \\
4 beta & $\mathrm{min}$ & 161 \\
Lambda $_{1}$ & $\mathrm{~min}-1$ & $0.0907 \pm 0.0280$ \\
Lambda $_{2}$ & $\mathrm{~min}-1$ & $0.0043 \pm 0.0009$ \\
$V_{1}$ & $\mathrm{ml} \cdot \mathrm{kg}^{-1}$ & $102 \pm 24$ \\
$V_{d b}$ & $\mathrm{ml} \cdot \mathrm{kg}^{-1}$ & $353 \pm 83$ \\
CL & $\mathrm{ml} \cdot \mathrm{kg}^{-1} \cdot \mathrm{min}^{-1}$ & $1.8 \pm 0.4$ \\
AUC & $\mu \mathrm{g} \cdot \mathrm{min}^{-1} \mathrm{ml}^{-1}$ & $110 \pm 25$ \\
\hline
\end{tabular}

The half-lives were calculated using $t=\ln 2 /$ ambda. 
TABLE V Renal clearance at various time intervals after the administration of pipccuronium bromide (mean \pm SD)

\begin{tabular}{lll}
\hline $\begin{array}{l}\text { Time after pipecuronium } \\
\text { administration (hour) }\end{array}$ & $\begin{array}{l}\text { Renal clearance } \\
\left(\mathrm{ml} \cdot \mathrm{kg}^{-1} \cdot \mathrm{min}^{-1}\right)\end{array}$ \\
\hline$t_{i}$ & $t_{j}$ & $0.71 \pm 0.46$ \\
\hline 0 & 2 & $1.29 \pm 0.72^{*}$ \\
2 & 4 & $1.19 \pm 0.54^{*}$ \\
4 & 6 & $1.62 \pm 0.74$ \\
6 & 8 &
\end{tabular}

All values, except those marked with an asterisk, differed significantly between each other $(P<0.05$ ). Statistics were carricd out using the paired $t$ test. See for interpretation of $t_{i}$ and $t_{j}$ the text.

method, but could be clearly identified in the urine. The renal clearance $\left(\mathrm{CL}_{R}\right)$, estimated from the two hourly collected urine samples is listed in Table V. Renal clearance was not constant in time, but increased showing its highest value six to eight hours after the administration of pipecuronium. The mean renal clearance calculated over 24 hours was $0.98 \mathrm{ml} \cdot \mathrm{kg}^{-1} \mathrm{~min}^{-1}$. The noncumulative urinary excretion of pipecuronium and 3desacetyl pipecuronium are shown in Figure 4.

\section{Discussion}

The haemodynamic study

The present and previous studies ${ }^{19-21}$ demonstrate that pancuronium produces, in most instances, a moderate increase in heart rate, presumably due to its vagolytic activity. This increase may, in part, counteract the haemodynamic effects of anaesthesia and result in a less pronounced decrease in cardiac output and blood pressure. The increase in heart rate was reported to be unrelated to dose, unpredictable ${ }^{22}$ and closely related to a higher incidence of myocardial ischaemia. ${ }^{23}$ It could be more than a coincidence that only the two patients in the pancuronium group, who did not receive beta blocking drugs, developed a more pronounced increase in heart rate. It has been clearly demonstrated by Karliczek et al. ${ }^{18}$ that general anaesthesia ia a powerful modulator of the autonomic balance. Heinonen et al. ${ }^{24}$ have shown a higher incidence of haemodynamic effects when pancuronium was supplemented by high-dose fentanyl anaesthesia, than in this study. These observations support the contention that the frequency and severity of the haemodynamic effects of neuromuscular blocking agents may be modulated by the technique and the depth of anaesthesia. The etomidate/piritramide infusion technique was selected for general anaesthesia because of its haemodynamic stability, compared with anaesthesia techniques when used in combination with pancuronium. ${ }^{18}$

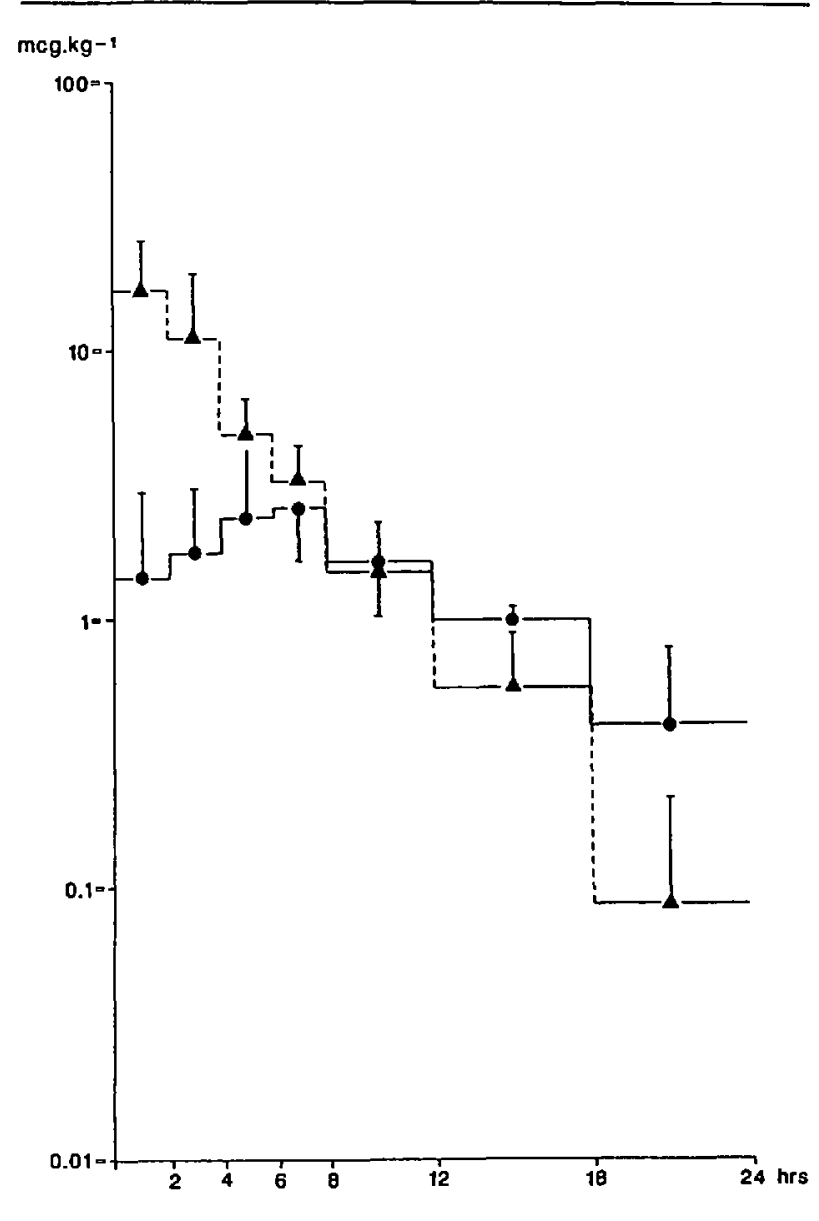

FIGURE 4 Mean urinary excretion rates of pipecuronium (A) and 3-desacetyl pipecuronium (†) indicated as $\mu \mathrm{g} \cdot \mathrm{kg}^{-1}$, per urinary fraction. The vertical bars indicate the standard deviation $(n=10)$.

This has been a consistent observation in studies in both animals and man. ${ }^{10.14}$ Unlike pancuronium, pipecuronium fails to counteract the negative chronotropic effect of opiate anaesthesia. ${ }^{3}$ Pipecuronium bromide in a bolus dose of $200 \mu \mathrm{g} \cdot \mathrm{kg}^{-1}$ did not produce tachycardia. Although vagolytic drugs were absent, neither unacceptably low heart rates nor ventricular escape beats were registered. Although significant decreases in systemic arterial systolic, diastolic and central venous and pulmonary capillary wedge pressures occurred with a concomitant significant decrease in cardiac output, these were associated with a relatively stable systemic vascular resistance together with significant reductions in rate pressure product, triple index and left ventricular power. In the present study one of the important effects of pipecuronium was the decrease in left ventricular power (decrease by 25 per cent; Table III), which parallelled the changes in the systemic arterial pressure. The resulting decrease in coronary perfusion pressure could result in a 
diminished oxygen delivery to the cardiac muscle. Sonntag, ${ }^{25}$ however has emphasized that diminished oxygen delivery following a decrease in arterial blood pressure might be compensated by an even more pronounced reduction in oxygen demand, which occurs due to a decrease in cardiac work. In the present study an additional slight decrease in diastolic arterial pressure with an unaltered diastolic time interval seemingly benefited the oxygen delivery/demand ratio in the pipecuronium-treated patients. The unchanged systemic vascular resistance after pipecuronium administration suggests that an indirect (alpha adrenergic blocking) or direct effect upon smooth muscle tone of blood vessels is unlikely in the clinical dose range. The improvement of the oxygen delivery/demand ratio, associated with the use of pipecuronium in this particular anaesthetic technique, may be of benefit for patients with ischaemic heart disease. The lack of cardiovascular effects with pipecuronium may unmask the negative inotropic and chronotropic effects due to induction of anaesthesia.

\section{The pharmacokinetic study}

The plasma concentration decay curve of pipecuronium following a bolus dose of $200 \mu \mathrm{g} \cdot \mathrm{kg}^{-1}$ is best described by a continuously declining bi-exponential curve. Caldwell et al. ${ }^{28}$ studied the pharmacokinetics of pipecuronium $\left(70 \mu \mathrm{g} \cdot \mathrm{kg}^{-1}\right)$ in patients, anaesthetized with halothane and nitrous oxide. The apparent distribution volume in our study $\left(\mathrm{V}_{\mathrm{d} \beta}=353 \pm 83 \mathrm{ml} \cdot \mathrm{kg}^{-1}\right)$ was of the same order of magnitude as that reported by Caldwell $\left(\mathrm{V}_{\mathrm{dss}}=\right.$ $309 \pm 103 \mathrm{ml} \cdot \mathrm{kg}^{-1}$ ) and the total plasma clearance of 1.8 $\pm 0.4 \mathrm{ml} \cdot \mathrm{kg}^{-1} \cdot \mathrm{min}^{-1}$ was almost identical to the value reported by Caldwell $\left(2.4 \pm 0.6 \mathrm{ml} \cdot \mathrm{kg}^{-1} \cdot \mathrm{min}^{-1}\right)$. The estimated half-life of pipecuronium during cardiopulmonary bypass approximated $157 \mathrm{~min}$ and did not differ significantly from the terminal half-life in this study (161 mins) or from the value reported by Caldwell (137 mins). The overall effect of hypothermia and bypass did not appear to influence the terminal half-life of pipecuronium when given in this dosage regime.

It has been reported that renal elimination of neuromuscular blocking agents decreases during hypothermia. ${ }^{26-29}$ In the present study the renal clearance of pipecuronium increased with time (see Table V). An explanation for this phenomenon could probably be diminished renal perfusion due to the relatively hypovolaemic preoperative state of our patients (high haematocrit value) in combination with the depressant effect on the cardiac output, caused by the induction of anaesthesia. We suggest that renal clearance most probably increases due to the haemodilution and improvement of the renal circulation during extra corporeal circulation. Rewarming the patient to normal body temperature (6-8 hr after induction of anaesthesia) led to a further improvement of renal clearance. The mean renal clearance over $24 \mathrm{hr}$ was $0.98 \mathrm{ml} \cdot \mathrm{kg}^{-1} \cdot \mathrm{min}^{-1}$ and the total plasma clearance amounted to $1.8 \mathrm{ml} \cdot \mathrm{kg}^{-1}$. $\min ^{-1}$ (Table IV). The ratio of the renal to total plasma clearance, therefore, is 0.54 . This is similar to the fraction of the administered dose of pipecuronium excreted in the urine $(0.56$, see Figure 3$)$ over the same time interval.

The plasma concentration decay of pipecuronium was observed for an eight-hour period (Figure 2). Calculating the mean renal clearance, using equation [5], means an extrapolation of the plasma concentration decay curve to $24 \mathrm{hr}$. The calculated ratio of 0.54 , using this equation [5], equals the measured fraction of the administered dose of pipecuronium, excreted in 24 hours in the urine. Therefore we conclude that the renal clearance, calculated by extrapolation of the plasma curve, appears to be reliable and the pharmacokinetic variables calculated over an eight-hour period and used to describe the plasma concentration decay curve are acceptable.

The percentage of pipecuronium excreted unchanged in the urine over $24 \mathrm{hr}$ accounted for 41 per cent of the administered dose (see Figure 3 ). This supports the observation that renal excretion contributes in a major degree to the total elimination of pipecuronium both in animal and in man. The question arises which mechanism(s) counteract(s) the effect of the increase in renal clearance in the course of the experiment, for total plasma clearance appeared to be constant. A progressive diminution in liver function and a subsequent decrease in hepatic storage, due to the hypothermic bypass, may be responsible for the obligatory reduction in non-renal clearance with time. Further investigations are necessary to elucidate the underlying mechanism(s) to this reciprocity of non-renal and renal clearance. In this study we found that 15 per cent of the administered dose of pipecuronium was excreted in the urine as 3-desacetoxy pipecuronium (see Figure 3). This is approximately one-fourth of the total renal excretion. Yet, we could not detect the 3-OH metabolite in plasma. The formation of the 3-OH metabolite from its parent compound was probably not constant in time as changes in temperature during cardiopulmonary bypass can alter the rate of metabolism. ${ }^{30}$ Because renal elimination was not constant and determination of the low plasma concentrations of 3-desacetyl pipecuronium was not possible, further analysis of urinary data was not feasible. Obviously, a more sensitive analytical technique is needed to elucidate the pharmacokinetic behaviour of 3-desacetoxy pipecuronium.

\section{Conclusions}

In the present study pipecuronium appeared to be a useful neuromuscular blocking agent for patients undergoing 
hypothermic coronary bypass surgery. The cardiovascular side-effects were potentially less deleterious than those of pancuronium, particularly with respect to heart rate. The pharmacokinetic profile of pipecuronium, given in a bolus dose of $200 \mu \mathrm{g} \cdot \mathrm{kg}^{-1}$ at induction of anaesthesia, appears to be similar to that observed after lower doses of pipecuronium in studies without hypothermic bypass. Pipecuronium seems to be a useful addition to drugs available for patients with heart disease, undergoing prolonged surgery.

\section{References}

1 Newton DEF, Richardson FJ, Agoston S. Preliminary studies in man with pipecuronium bromide (Arduan), a new steroid neuromuscular blocking agent. $\mathrm{Br} \mathrm{J}$ Anaesth 1982; 54: 789P-90P.

2 Wierda JMKH, Richardson FJ, Agoston S. Dose-response relationship and time-course of action of pipecuronium bromide under isoflurane, halothane and neurolept anaesthesia. Br J Anacsth 1989; 62: 194-8.

3 Karpati $E$, Biro $K$. Pharmacological study of a new competitive neuromuscular blocking steroid, pipecurium bromide. Arzneimittelforschung 1980; 30: 346-54.

4 Agoston S, Vandenbrom RHG, Wierda JMKH, Houwertjes $M C$, Kersten $U W$. Pharmacokinetics and disposition of pipecuronium bromide in the cat. Eur J Anaesthesiol 1988; 5: 233-42.

5 Bodrogi L, Fehér T, Váradi A, Vereczkey L. Pharmacokinctics of pipecurium bromide in the rat. Arzneimittelforschung 1980; 30: 366-70.

6 Tassonyi E, Szabó G, Vereczkey L. Pharmacokinetics of pipecurium bromide, a new non-depolarizing neuromuscular blocking agent, in humans. Arzncimittelforschung 1981; 31: $1754-6$.

7 Tassonyi E, Szabo G, Vimlati L. The use of pipecuronium bromide (Arduan $\left.{ }^{(}\right)$in anesthesiology. In: Kharkevich DA (Ed.). Handbook of Experimental Pharmacology, Vol. 79, Berlin-Heidelberg: Springer Verlag, 1986: 599-616.

8 Caldwell JE, Canfell PC, Castagnoli KP, et al. The influence of renal failure on the pharmacokinetics and the duration of action of pipecuronium bromide in patients anesthetized with halothane and nitrous oxide. Anesthesiology 1989; 70: 7-12.

9 Alant O, Darvas K, Pulay I, Weliner J, Bihari I. First clinical experience with a new neuromuscular blocker pipecurium bromide. Arzneimittelforschung 1980; 30: 374-9.

10 Alyautdin RN, Buyanov VV, Frisenko VP et al. On some properties of a new steroid curare-like compound pipecurium bromide. Arzneimittelforschung 1980; 30: 355-7.
11 Bunjatjan AA, Miheev VI. Clinical experience with a new steroid muscle relaxant: pipecurium bromide. Arzneimittelforschung 1980; 30: 383-5.

12 Pulay I, Alánt $O$, Darvas $K$, Weltner J, Zétény Zs. Respiration paralysing and circulatory effects of a new non-depolarizing relaxant, pipccurium bromide, in anaesthetized dogs. Arzneimittelforschung 1980; 30: 358-60.

13 Maestrone E, Torri G, Pradella $G$ et al. Valutazione comparativa del blocco neuromuscolare e della risposta cardiovascolare dopo somministrazione di pancuronio o pipecuronio. Anestesia e Rianimazione 1987; 28: 103-8.

14 Barankay $A$. Circulatory effects of pipecurium bromide during anaesthesia of patients with severe valvular and ischaemic heart disease. Arzneimittelforschung 1980; 30 : 386-9.

15 Karliczek GF, de Geus AF, Wiersma G, Oosterhaven S, Jenkins l. Carola, a computer system for automatic documentation in anesthesia. International Journal of Clinical Monitoring and Computing 1987; 4: 211-21.

16 Kersten UW, Meijer DKF, Agoston S. Fluorimetric and chromatographic determination of pancuronium bromide and its metabolites in biological materials. Clin Chim Acta 1973; 44: 59-66.

17 Scaf $A H J$. Pharmacokinetic analyses with RUGFIT; an interactive pharmacokinetic computer program. Biopharm Drug Dispos 1988; 9: 415-46.

18 Karliczek GF, Brenken U, Agnew M. Narkosceinleitung mit Etomidate und Piritramid bei Patienten mit Koronarsklerose oder Klappenfehlern. Anaesthesist 1980; 29: 1-11.

19 Shulman B, Manos J, Feinberg B, Mora C, LaMantia K, Silvay $G$. Hemodynamic effects of pancuronium vs. vecuronium during sufentanil induction for $\mathrm{CABG}$. Anesthesiology 1985; 63: A99.

20 Sethna DH, Starr NJ, Estafanous FG. Cardiovascular effects of non-depolarizing neuromuscular blockers in patients with coronary artery disease. Can Anaesth Soc J 1986; 33: 280-6.

21 Ferres CJ, Carson IW, Lyons SM, Orr IA, Patterson CC, Clarke RSJ. Haemodynamic effects of vecuronium, pancuronium and atracurium in patients with coronary artery disease. $\mathrm{Br} J$ Anaesth 1987; 59: 305-11.

22 MillerRD, Eger II El, Stevens WC, Gibbons R. Pancuroniuminduced tachycardia in relation to alveolar halothanc, dose of pancuronium, and prior atropine. Anesthesiology 1975; 42: 352-5.

23 Thomson IR, Putnins CL. Adverse effects of pancuronium during high-dose fentanyl anesthesia for coronary artery bypass grafting. Anesthesiology 1985; 62: 708-13. 
24 Heinonen J, Salmenperä $M$, Suomivuori $M$. Contribution of muscle relaxant to the haemodynamic course of high-dose fentanyl anaesthesia; a comparison of pancuronium, vecuronium and atracurium. Can Anaesth Soc J 1986; 33: 597-605.

25 Sonntag $H$, Larsen $R$, Hilfiker $O$, Kettler D, Brockschnieder $B$. Myocardial blood flow and oxygen consumption during high-dose fentanyl anesthesia in patients with coronary artery disease. Anesthesiology 1982; 56: 417-22.

$26 d$ 'Hollander AA, Duvaldestin P, Henzel D, Nevelsteen $M$, Bomblet $J P$. Variations in pancuronium requirement, plasma concentration, and urinary excretion induced by cardiopulmonary bypass with hypothermia. Anesthesiology 1983; 58: 505-9.

27 Miller RD, Agoston S, Van der Pol F, Booij LHDJ, Crul $J F$, Ham J. Hypothermia and the pharmacokinetics and pharmacodynamics of pancuronium in the cat. $J$ Pharmacol Exp Ther 1978; 207: 532-8.

28 Walker JS, Shanks CA, Brown $K F$. Altered d-tubocurarine disposition during cardiopulmonary bypass surgery.

Clin Pharmacol Ther 1984; 35: 686-94.

29 Walker $J S$, Brown $K F$, Shanks $C A$. Alcuronium kinetics in patients undergoing cardiopulmonary bypass surgery. Br J Clin Pharmacol 1983; 15: 237-44.

30 Holley FO, Ponganis KV, Stanski DR. Effect of cardiopulmonary bypass on the pharmacokinetics of drugs. Clin Pharmacokin 1982; 7: 234-51. 